\title{
Physicochemical and Spectral Characterization of Biofield Energy Treated 4-Methylbenzoic Acid
}

\author{
Mahendra Kumar Trivedi ${ }^{1}$, Alice Branton ${ }^{1}$, Dahryn Trivedi ${ }^{1}$, Gopal Nayak $^{1}, \operatorname{Ragini} \operatorname{Singh}^{2}$, \\ Snehasis Jana ${ }^{2, *}$ \\ ${ }^{1}$ Trivedi Global Inc., Henderson, USA \\ ${ }^{2}$ Trivedi Science Research Laboratory Pvt. Ltd., Bhopal, Madhya Pradesh, India
}

Email address:

publication@trivedisrl.com (S. Jana)

\section{To cite this article:}

Mahendra Kumar Trivedi, Alice Branton, Dahryn Trivedi, Gopal Nayak, Ragini Singh, Snehasis Jana. Physicochemical and Spectral Characterization of Biofield Energy Treated 4-Methylbenzoic Acid. American Journal of Chemical Engineering.

Vol. 3, No. 6, 2015, pp. 99-106. doi: 10.11648/j.ajche.20150306.14

\begin{abstract}
The present study was aimed to analyse the impact of biofield energy treatment on the physicochemical and spectral properties of 4-MBA. The compound was divided into two parts which are referred as the control and treated sample. The treated sample was subjected to Mr. Trivedi's biofield energy treatment and analysed with respect to the control sample. The various analytical techniques used were X-ray diffraction (XRD), surface area analysis, differential scanning calorimetry (DSC), thermogravimetric analysis (TGA), Fourier transform infrared (FT-IR), and UV-visible spectroscopy. The XRD data revealed the alteration in the relative intensities of the peaks as well as reduction in the average crystallite size (24.62\%) of the treated sample as compared to the control. The surface area analysis revealed a slight reduction in the surface area of the treated sample. The differential scanning calorimetry analysis reported a slight increase in the melting point while significant reduction in the latent heat of fusion of the treated sample (39.96 J/g) as compared to the control $(133.72 \mathrm{~J} / \mathrm{g})$. Moreover, the TGA thermogram of the treated sample revealed the reduction in the onset temperature and maximum thermal degradation temperature as compared to the control. However, the FT-IR and UV-Vis spectra of treated sample did not show any significant alteration as compared to their respective control spectra. The overall data indicated the improved physical and thermal properties of the biofield treated 4-MBA sample that might be helpful in increasing the reaction kinetics, where it will be used as a reaction intermediate.
\end{abstract}

Keywords: 4-Methylbenzoic Acid, Biofield Energy Treatment, Reaction Kinetics, Thermal Analysis

\section{Introduction}

Benzoic acid is belonging to the family of aromatic carboxylic acids and has wide applications in the manufacturing of dyes, plastics, insect repellents, and some cosmetics [1]. Its salt derivatives are also used in preservation of food ingredients, e.g. sodium benzoate [2]. It has anti-fungal properties and causes the growth inhibition of bacteria, moulds, and yeasts, which makes it suitable candidate for use as a preservative [3]. In cosmetic industry, it is used in toothpastes, mouthwashes, lipsticks, and the facial cleanser. Similarly, in pharmaceutical industry it acts as a basic constituent of Whitfield's ointment i.e. used for treating the fungal skin diseases. Other pharmaceutical uses include as a topical antiseptic, analgesic, expectorant, and decongestant $[4,5]$. 4-Methylbenzoic acid (4-MBA) is a substituted benzoic acid, which is also used in the chemical and pharmaceutical industries. It is a crystalline solid having solubility in acetone but insoluble in the water [6]. It acts as an intermediate in the manufacturing of polyethylene terephthalate for the oxidation of $p$-xylene to terephthalic acid [7]. Other uses include as an intermediate for synthesis of pesticides, polymer stabilizers, light sensitive compounds, pigments, dyestuffs, and other organic and pharmaceutical compounds [8].

The chemical kinetics of any reaction depends on the relative rate of all chemical reactions involved as well as the physicochemical properties of the intermediate compound [9]. It was previously reported that the parameters such as crystallite size, surface area, and thermal properties are important determinants of the rate of reaction $[10,11]$. Hence, the current study was designed for analysing the impact of biofield energy treatment on the physicochemical as well as spectral properties of 4-MBA. 
The human bioenergy concept was originated thousand years back and nowadays, it is scientifically termed as the biologically produced energy fields that are basically related with the regulatory and communication functions inside the body [12]. Besides, the practitioners of this energy fields have the ability to channelize the supraphysical energy and intentionally direct this energy towards the target [13]. It has been reported that the biofield energy therapies have their therapeutic potential for improving the functional ability of arthritis patients, enhancing the personal well-being, and decreasing the pain and anxiety $[14,15]$. Thus, a human can harness the energy from the environment and can transmit into any living or non-living object(s). The objects receive this energy and respond in a useful manner. This phenomenon is known as biofield energy treatment. Mr. Trivedi is a well-known practitioner of biofield energy treatment, which is also called as The Trivedi Effect ${ }^{\circledR}$. His treatment is known for its impact in various microorganisms [16], plants [17], and agricultural products [18]. The impact of biofield energy treatment was also reported on various organic and pharmaceutical compounds [19]. Hence, after considering the importance of 4-MBA as an intermediate compound, the current study was designed to analyse the impact of biofield energy treatment on the physicochemical and spectral properties of 4-MBA. The techniques used in the study were X-ray diffraction, surface area analysis, thermal analysis, and spectroscopic analyses using Fourier transform infrared and UV-visible spectroscopy.

\section{Materials and Methods}

4-Methylbenzoic acid was procured from Loba Chemie Pvt. Ltd., India. In treatment methodology, the procured sample was divided into two parts, and one part was handed over to Mr. Trivedi in sealed pack under standard laboratory conditions. Mr. Trivedi provided the treatment to this part through his unique energy transmission process, without touching the sample; and this part was coded as the treated sample. The other part was remained as untreated and coded as the control sample. Both the samples were subsequently analysed using various analytical techniques as mentioned below and their results were compared.

\subsection{X-ray Diffraction (XRD) Study}

The Phillips Holland PW 1710 X-ray diffractometer was used to obtain the X-ray powder diffractograms of the control and treated samples. The instrument was equipped with a copper anode with nickel filter (operating parameters: $35 \mathrm{kV}$, $20 \mathrm{~mA}$, and $1.54056 \AA$ wavelength radiation). The Bragg's angle at which peaks were obtained was recorded and compared with the control sample for any deviation in angle. Besides, the data was used to calculate the average crystallite size (G) using Scherrer equation:

$$
\mathrm{G}=\mathrm{k} \lambda /(\mathrm{b} \operatorname{Cos} \theta)
$$

Here, $\mathrm{k}$ is constant $(0.94), \lambda$ is the $\mathrm{X}$-ray wavelength $(0.154$ $\mathrm{nm}), \mathrm{b}$ in radians is the full-width at half of the peak and $\theta$ is the corresponding Bragg's angle.

\subsection{Surface Area Analysis}

The Brunauer-Emmett-Teller (BET) surface area analyser, Smart SORB 90 was used to calculate the surface area of the control and treated sample. It has a measuring range of 0.2 $\mathrm{m}^{2} / \mathrm{g}$ to $1000 \mathrm{~m}^{2} / \mathrm{g}$. The percent change in surface area was calculated to determine the difference between control and the treated samples.

\subsection{Differential Scanning Calorimetry (DSC)}

DSC of Perkin Elmer/Pyris-1 was used for studying the parameters related to melting behaviour of the 4-MBA sample. The DSC curves were recorded under air atmosphere (5 $\mathrm{mL} / \mathrm{min}$ ) and a heating rate of $10^{\circ} \mathrm{C} / \mathrm{min}$ in the temperature range of $50^{\circ} \mathrm{C}$ to $350^{\circ} \mathrm{C}$. From DSC curve, the melting temperature and latent heat of fusion $(\Delta \mathrm{H})$ of control and treated samples were obtained and compared to analyse the impact of biofield treatment.

\subsection{Thermogravimetric Analysis / Differential Thermal Analysis (TGA/DTA)}

The thermal degradation pattern of 4-MBA was analysed using Mettler Toledo simultaneous thermogravimetric analyser (TGA/DTA). The temperature range was selected from room temperature to $320^{\circ} \mathrm{C}$ with a heating rate of $5^{\circ} \mathrm{C}$ $/$ min under air atmosphere. The data was obtained in the form of TGA, DTA, and DTG ( $1^{\text {st }}$ derivative thermogram) curve. The impact of biofield treatment was analysed by comparing the results of these curves in the treated sample with that of control sample.

\subsection{Spectroscopic Analysis}

\subsubsection{Fourier Transform-Infrared (FT-IR) Spectroscopic Characterization}

The FT-IR spectra were recorded on Shimadzu's Fourier transform infrared spectrometer (Japan) in the frequency range $4000-450 \mathrm{~cm}^{-1}$. The spectra were obtained in the form of wavenumber vs. percentage transmittance. The obtained spectra of control and treated samples were compared for analysing the impact of biofield energy on the bond length and bond angle of various functional groups present in the medium.

\subsubsection{UV-Vis Spectroscopic Analysis}

The UV-Vis spectrum of 4-MBA was recorded in methanol solvent by Shimadzu UV-2400 PC series spectrophotometer. The spectrum was recorded over a wavelength range of 200-400 $\mathrm{nm}$ with $1 \mathrm{~cm}$ quartz cell and a slit width of $2.0 \mathrm{~nm}$. The analysis was performed to evaluate the effect of biofield energy treatment on the spectral properties of 4-MBA sample. 


\section{Results and Discussion}

\subsection{X-ray Diffraction (XRD)}

A series of sharp peaks were observed in the diffractograms of control and treated samples (Fig. 1) in the regions of $10^{\circ}<2 \theta>40^{\circ}$. The control sample showed the most intense peak at $2 \theta$ equal to $17.27^{\circ}$; however, in treated sample it was observed at $26.65^{\circ}$. It indicated that the biofield treatment might cause an alteration in the relative intensities of XRD peaks in the treated sample as compared to the control. It is reported that the alteration in relative intensities of the peaks may occur due to change in the crystal morphology [20]. Besides, the 4-MBA molecules have $\mathrm{O}-\mathrm{H} \cdots \mathrm{O}$ carboxylic acid dimer synthon (structural unit within the molecule) in its crystal structure [21]. Hence, it is assumed that the biofield energy treatment might cause some alteration in these synthon molecules that further affect the relative intensities of the peaks. Further, the average crystallite size of the control and treated samples were calculated using the Scherrer equation. The data reported that the crystallite size of the control sample was $125.99 \mathrm{~nm}$, whereas in the treated sample it was found as $94.97 \mathrm{~nm}$. It revealed that the average crystallite size of the treated sample was significantly reduced by $24.62 \%$ as compared to the control. The decreased crystallite size may be due to biofield energy, which might induce strain in the lattice and that possibly resulted into fracturing of grains into sub grains and hence decreased crystallite size [22]. 4-MBA is used as an intermediate in the synthesis of many chemical and pharmaceutical compounds; hence, the decrease in crystallite size may lead to fasten the rate kinetics, which ultimately enhances the percentage yield of the end products [11].
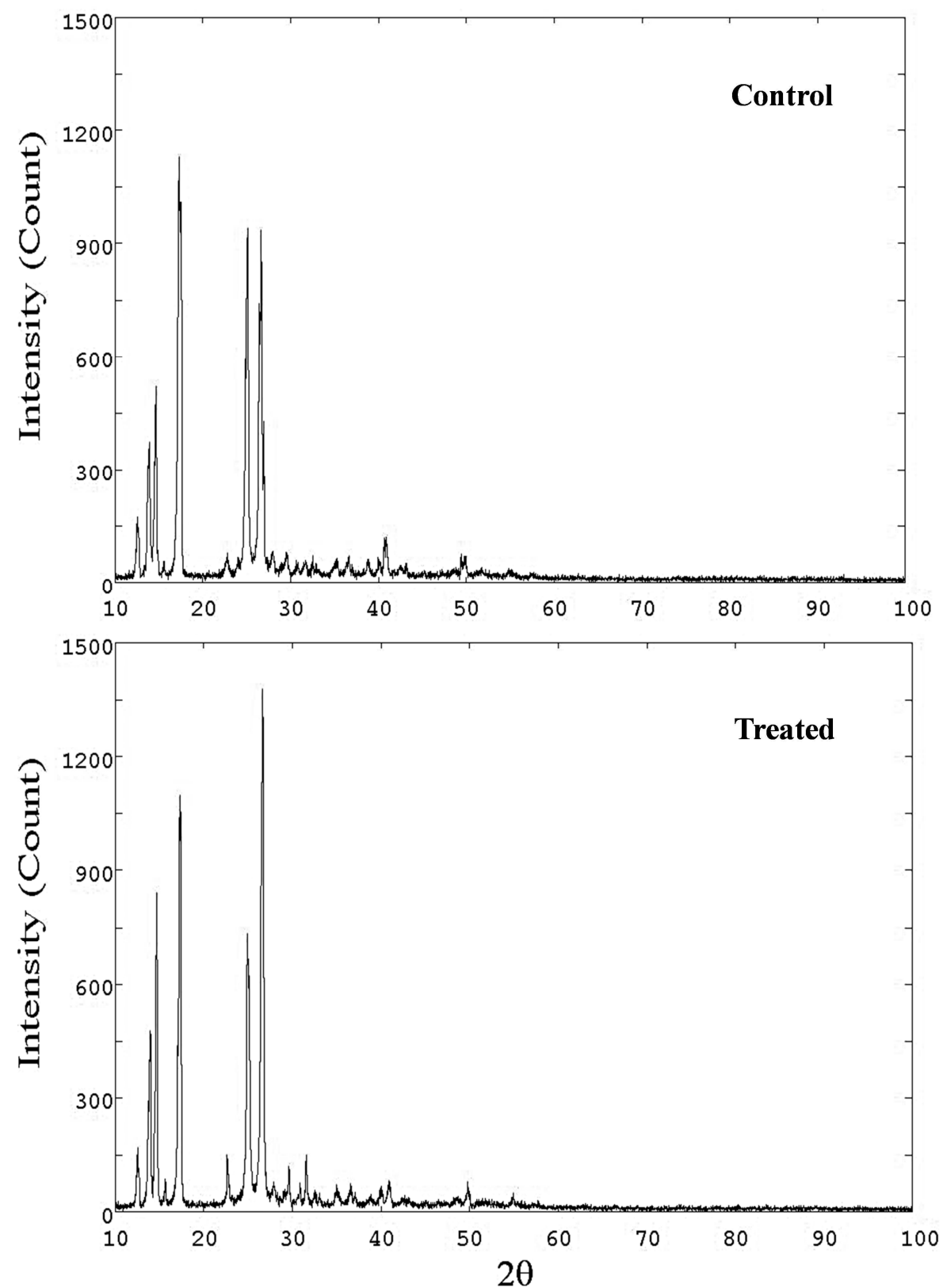

Fig. 1. XRD diffractograms of control and treated samples of 4-methylbenzoic acid. 


\subsection{Surface Area Analysis}

The surface area analysis was done to observe the impact of biofield energy treatment on the surface area of the treated sample, which is indirectly related with the particle size. The results showed that the control sample had a surface area of $0.203 \mathrm{~m}^{2} / \mathrm{g}$; however, the treated sample showed a surface area of $0.200 \mathrm{~m}^{2} / \mathrm{g}$. The result showed a slight decrease $(1.48 \%)$ in the surface area of the treated sample as compared to the control. The possible reason behind it might be the biofield energy treatment that may cause some alteration in the particle size of the treated sample [23].

\subsection{DSC Analysis}

The DSC analysis data (Table 1) reported the presence of endothermic curve in the control sample at $180.70^{\circ} \mathrm{C}$ that was slightly shifted to higher temperature and observed at $181.61^{\circ} \mathrm{C}$ in the treated sample. The endothermic curve was due to the melting of 4-MBA sample. Moreover, the onset and endset temperature were also shifted correspondingly to higher temperature in the treated sample as compared to the control. The slight increase in melting temperature might occur due to decrease in the surface area of the treated sample. Besides, the change in crystal symmetry due to biofield energy treatment might be another reason for this observation [24].

Table 1. DSC analysis of control and treated samples of 4-methylbenzoic acid.

\begin{tabular}{lll}
\hline Parameter & Control & Treated \\
\hline Onset temperature $\left({ }^{\circ} \mathrm{C}\right)$ & 179.23 & 180.48 \\
Peak temperature $\left({ }^{\circ} \mathrm{C}\right)$ & 180.70 & 181.61 \\
Endset temperature $\left({ }^{\circ} \mathrm{C}\right)$ & 181.21 & 183.51 \\
Latent heat of fusion $\Delta \mathrm{H}(\mathrm{J} / \mathrm{g})$ & 133.72 & 39.96 \\
\hline
\end{tabular}

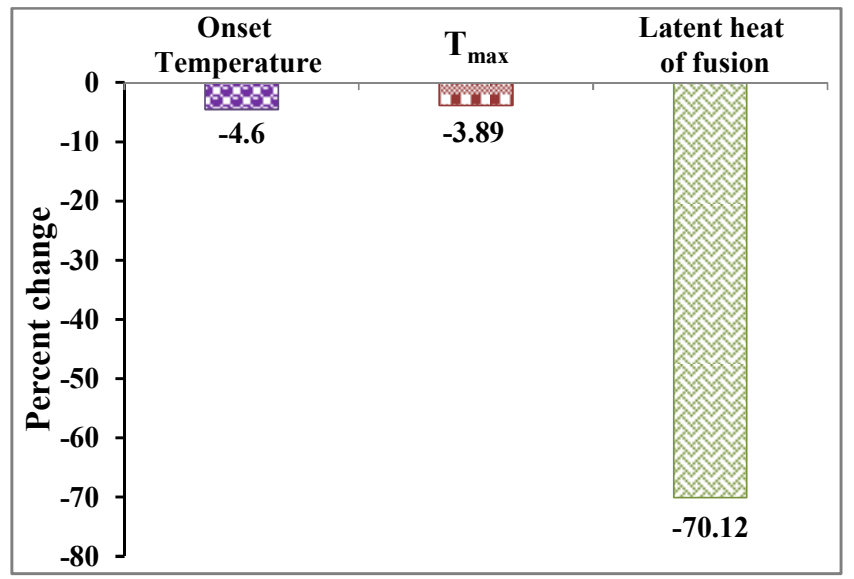

Fig. 2. Percent change in onset temperature, $T_{\max }$ and latent heat of fusion in biofield energy treated 4-methylbenzoic acid.

Further, the $\Delta \mathrm{H}$ values were recorded from the thermograms and the data showed that the enthalpy change during the phase change of 4-MBA from solid to liquid [25] was $133.72 \mathrm{~J} / \mathrm{g}$ in the control sample; whereas, it was reduced to $39.96 \mathrm{~J} / \mathrm{g}$ in the treated sample (Fig. 2). As the enthalpy is related with the internal energy, the reduction in its value in the treated sample suggested that the treated sample was already in a high energy state, hence need less energy to undergo the phase change i.e. melting [26].

\subsection{TGA/DTA Analysis}

The TGA/DTA studies are helpful in analysing the thermal decomposition pattern of the sample during heating. The TGA/DTA thermograms of the control and treated samples of 4-MBA are shown in Fig. 3. The TGA thermogram represents the onset and endset temperature of degradation along with the percent weight loss of the sample during heating. The control sample showed the thermal degradation in the range of $174-230^{\circ} \mathrm{C}$ with a weight loss of $68.54 \%$ of the initial weight of the sample. This temperature range is similar to the melting range of 4-MBA sample as reported by the DSC analysis. Hence, the weight loss of the sample might be due to the volatilization of the 4-MBA sample. Besides, the treated sample showed the weight loss of $64.29 \%$ in the temperature range $166-234^{\circ} \mathrm{C}$. The data showed a significant decrease in the onset of thermal degradation that might be related to the early volatilization of the treated sample as compared to the control. The DTA curve showed two peaks in the thermograms of the control and treated samples. In control sample, the first peak was observed at $178.92^{\circ} \mathrm{C}$ and the second peak was observed at $209.46^{\circ} \mathrm{C}$. The first peak was considered as the melting peak, whereas the second peak was assigned to the thermal degradation of the sample. Similarly, in treated sample, the corresponding peaks were observed at $181.31^{\circ} \mathrm{C}$ and $201.26^{\circ} \mathrm{C}$. The DTA data showed the increase in melting temperature along with the reduction in the thermal degradation temperature of the treated sample as compared to the control. The observation was supported by the DSC and TGA analysis. Besides, DTG thermogram data showed that $\mathrm{T}_{\max }$ was observed at $198.31^{\circ} \mathrm{C}$ in the control sample while $190.59^{\circ} \mathrm{C}$ in the treated 4-MBA sample. A possible reason for this reduction in $T_{\max }$ is that biofield energy treatment might cause some alteration in internal energy, which results into earlier volatilization of treated 4-MBA sample as compared to the control. The similar results were also reported by the other biofield treated benzoic acid derivatives [27]. Moreover, the state of reactant may affect the rate of reaction as the gases react faster than solid and liquids [28]. Apart from that, it was previously reported that vapour phase reaction can be more beneficial as compared to liquid phase reaction in terms of reaction time, generation of undesired by-products and objectionable amounts of odour $[29,30]$. Hence, the significant reduction in the onset temperature and $\mathrm{T}_{\max }$ (Fig. 2) suggested that biofield treated 4-MBA can be used as an intermediate in various chemical reactions with high reaction rate and increased percentage yield of end product. 

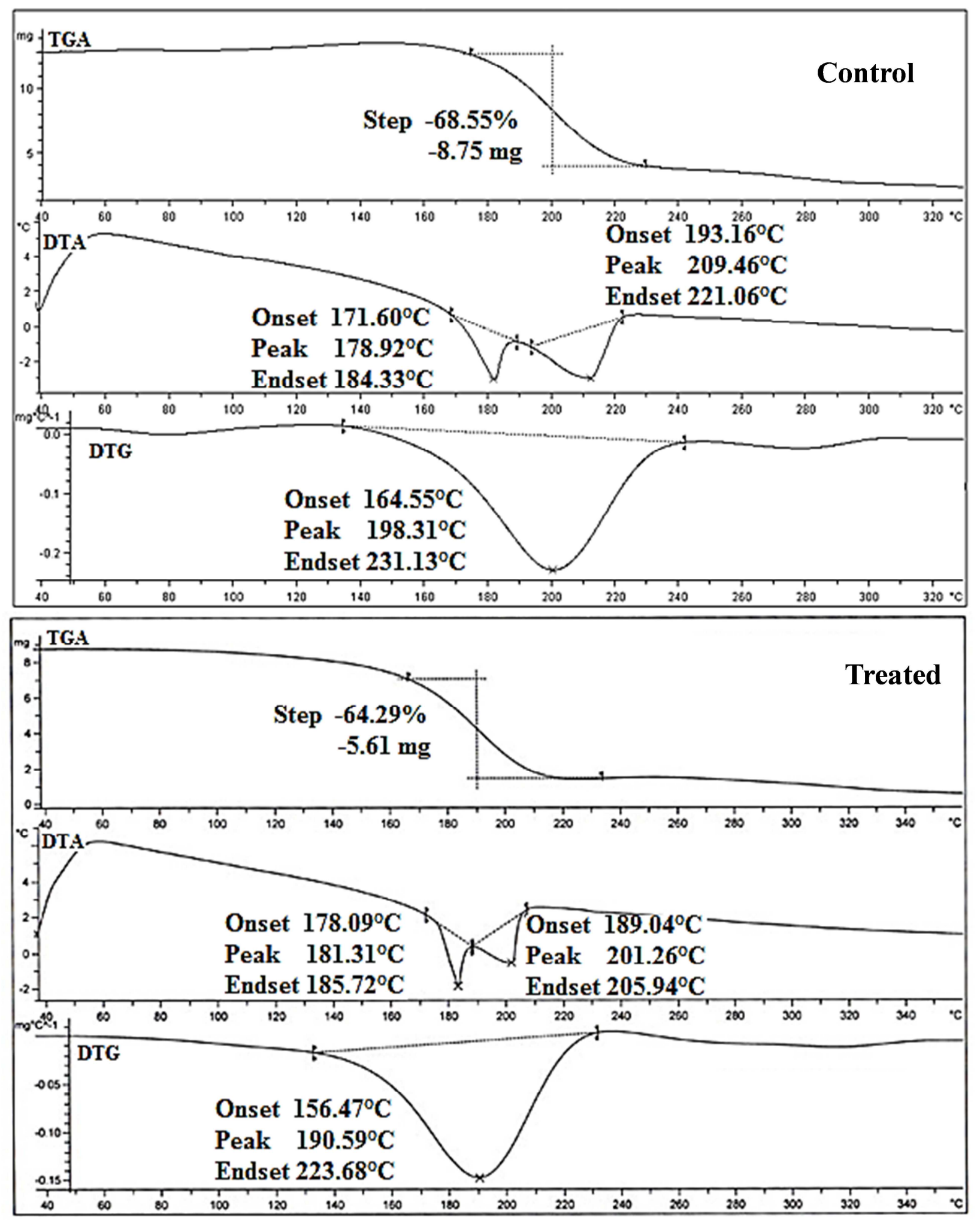

Fig. 3. TGA/DTA thermogram of control and treated samples of 4-methylbenzoic acid.

\subsection{Spectroscopic Analysis}

\subsubsection{FT-IR Spectroscopic Analysis}

The FT-IR spectra of 4-MBA (control and treated samples) are shown in Fig. 4. It showed similar kind of peaks in both, the control and treated samples and at similar frequencies. The peaks in range $2976-2551 \mathrm{~cm}^{-1}$ in the control sample were observed due to the H-bonded $\mathrm{O}-\mathrm{H}$ stretching and $\mathrm{C}-\mathrm{H}$ stretching groups. In the treated sample, the similar peaks were observed in the frequency range of $2976-2553 \mathrm{~cm}^{-1}$. The 
$\mathrm{C}=\mathrm{O}$ stretching peak of carboxylic acid group was observed at $1681 \mathrm{~cm}^{-1}$ in both, the control and treated samples. Similarly, the $\mathrm{C}=\mathrm{C}$ stretching and the ring stretching peaks were observed at 1612 and $1516 \mathrm{~cm}^{-1}$, respectively in both, the control and treated samples. Moreover, the peak due to $\mathrm{O}-\mathrm{H}$ and $\mathrm{CH}_{3}$ bending was observed at $1417 \mathrm{~cm}^{-1}$ in the control as well as the treated sample. The $\mathrm{C}-\mathrm{O}$ stretching peak was observed at $1286 \mathrm{~cm}^{-1}$ in the control and treated samples. The out-of-plane bending peak of para-substituted ring and the $\mathrm{O}-\mathrm{C}=\mathrm{O}$ bending peak were observed at 756 and $607 \mathrm{~cm}^{-1}$, respectively in both the control and treated samples. Similarly, the peaks due to ring deformation and $\mathrm{C}-\mathrm{C}=\mathrm{O}$ bending were appeared at 543 and $470 \mathrm{~cm}^{-1}$, respectively in both the control and treated samples. The spectra of the 4-MBA samples were well supported by the literature [31-33]. The data showed that there was no difference between the spectra of control and treated sample, which suggested that biofield energy treatment did not cause any alteration in the structural and bonding properties like bond strength, stability, rigidity of structure, etc. [34].

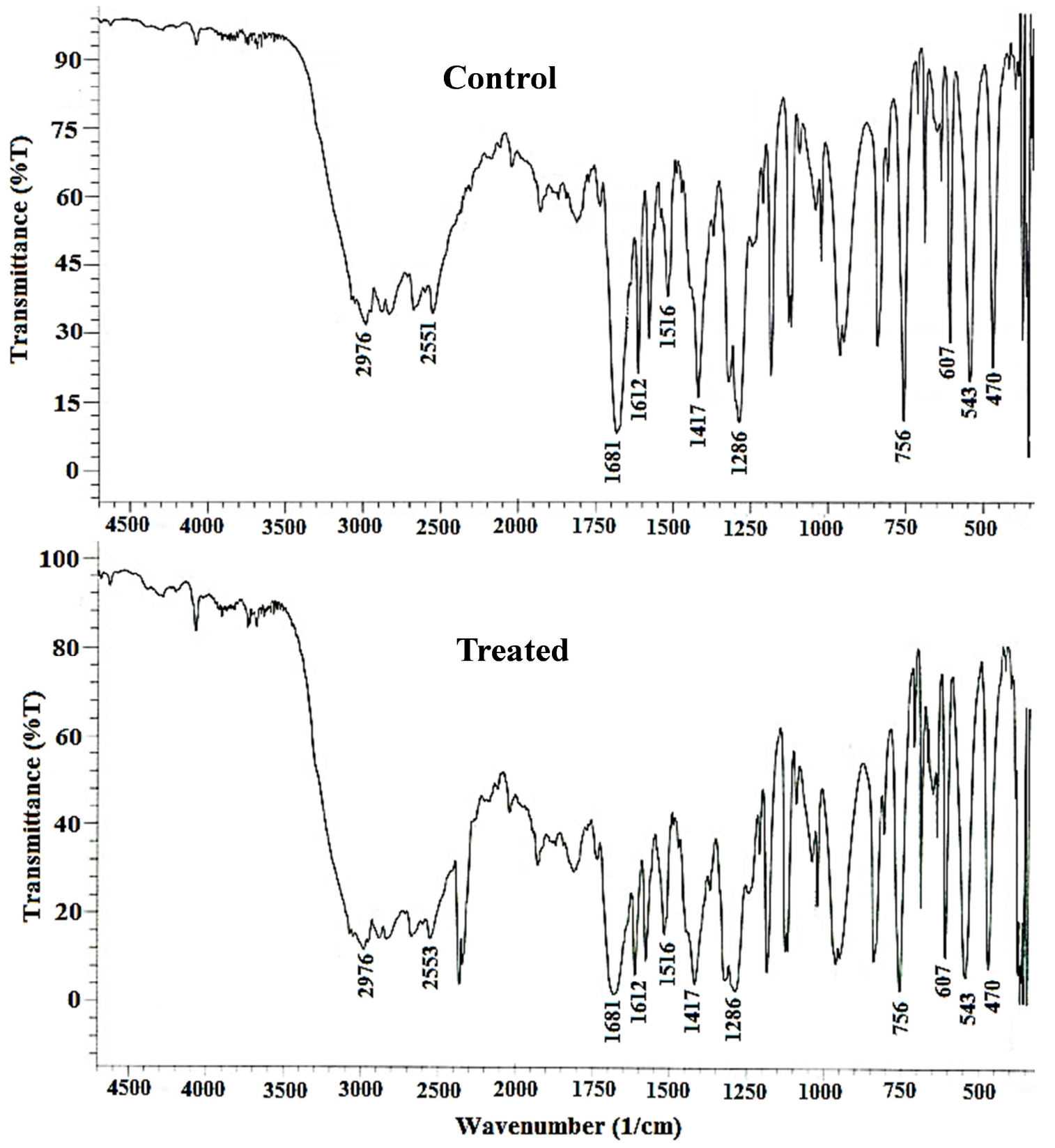

Fig. 4. FT-IR spectra of control and treated samples of 4-methylbenzoic acid.

\subsubsection{UV-Vis Spectroscopic Analysis}

The UV spectra of control and treated samples of 4-MBA are shown in Fig. 5. The UV spectrum of control sample showed characteristic absorption peaks at 204 and $235 \mathrm{~nm}$. The treated sample also showed the similar peaks at 203 and $235 \mathrm{~nm}$. The UV spectra of 4-MBA samples were well supported by the literature data [35]. It suggested that the biofield energy treatment could not make any alteration in chemical structure or arrangement of functional groups of treated 4-MBA sample. 

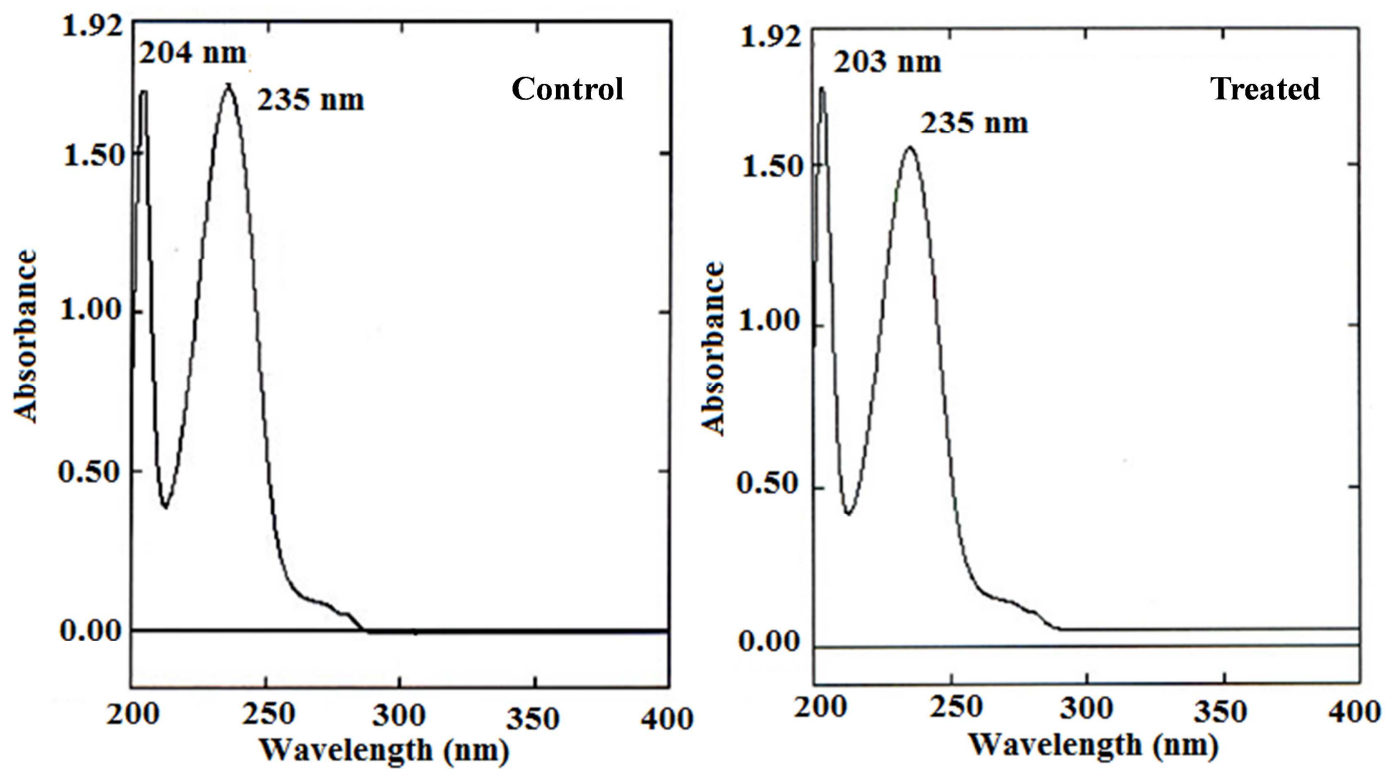

Fig. 5. UV-Vis spectra of control and treated samples of 4-methylbenzoic acid.

\section{Conclusions}

The XRD results showed that the relative intensities of the peaks were altered in the treated sample as compared to the control suggesting the impact of biofield energy treatment on the crystal symmetry and morphology of 4-MBA.

The crystallite size was decreased by $24.62 \%$ in the treated samples as compared to the control that might be due to the fracturing of grains into sub grains caused by the lattice strain that may be produced via biofield energy.

The reduced crystallite size may lead to increase the reaction kinetics of 4-MBA, which could make it more useful as an intermediate compound.

Moreover, the surface area analysis showed a slight decrease in the surface area of the treated sample that suggested the impact of biofield treatment on the particle size of the treated 4-MBA sample.

The thermal analysis data revealed that the latent heat of fusion was reduced by $70 \%$ in the treated sample as compared to the control.

TGA/DTA studies showed that onset temperature and $\mathrm{T}_{\max }$ was reduced in the treated sample. Based on this, it is hypothesized that treated 4-MBA molecules turn into vapour phase at lower temperature as compared to the control. The lowering of volatilization temperature might enhance the rate of reaction.

Therefore, it is assumed that biofield treated 4-MBA could be more useful as an intermediate in production of various chemical and pharmaceutical products.

\section{Acknowledgements}

Authors greatly acknowledge the support of Trivedi Science, Trivedi Master Wellness and Trivedi Testimonials in this research work. The authors would also like to thank the whole team from the Sophisticated Analytical Instrument
Facility (SAIF), Nagpur and MGV Pharmacy College, Nashik for providing the instrumental facility.

\section{References}

[1] Rose J, Moore MS (2001) Herbs \& things: Jeanne Rose's herbal. (2ndedn), Last Gasp, San Fransisco, USA.

[2] El-Ziney MG (2009) GC-MS analysis of benzoate and sorbate in Saudi dairy and food products with estimation of daily exposure. J Food Technol 7: 127-134.

[3] Krisch J, Tserennadmid R, Vagvolgyi C (2011) Essential oils against yeasts and moulds causing food spoilage. Science against microbial pathogens: Communicating current research and technological advances, Badajoz, Spain.

[4] Wibbertmann A, Kielhorn J, Koennecker G, Mangelsdorf I, Melber C (2005) Benzoic acid and sodium benzoate. Concise international chemical assessment document 26, World Health Organization, Geneva.

[5] Wilson CO, Gisvold O, Block JH (2004) Wilson and Gisvold's textbook of organic medicinal and pharmaceutical. Lippincott Williams \& Wilkins.

[6] https://pubchem.ncbi.nlm.nih.gov/compound/4-Methylbenzoic _acid

[7] Xiao Y, Luo WP, Zhang XY, Guo CG, Liu Q, et al. (2010) Aerobic oxidation of $p$-toluic acid to terephthalic acid over $\mathrm{T}(\mathrm{p}-\mathrm{Cl}) \mathrm{PPMnCl} / \mathrm{Co}(\mathrm{OAc})_{2}$ under moderate conditions. Catal Lett 134: 155-161.

[8] Budavari S, O'Neil M, Smith A, Heckelman P, Obenchain J (1996) The Merck Index: An encyclopedia of drugs, chemicals, and biological. (12thedn), Merck and Company.

[9] Laidler KJ (2008) Chemical Kinetics. (3rdedn), Pearson Education.

[10] Carballo LM, Wolf EE (1978) Crystallite size effects during the catalytic oxidation of propylene on $\mathrm{Pt} / \gamma-\mathrm{Al}_{2} \mathrm{O}_{3}$. J Catal 53: 366-373. 
[11] Chaudhary AL, Sheppard DA, Paskevicius M, Pistidda C, Dornheim M, et al (2015) Reaction kinetic behaviour with relation to crystallite/grain size dependency in the $\mathrm{Mg}-\mathrm{Si}-\mathrm{H}$ system. Acta Mater 95: 244-253.

[12] Movaffaghi Z, Farsi M (2009) Biofield therapies: Biophysical basis and biological regulations? Complement Ther Clin Pract 15: $35-37$

[13] Mager J, Moore D, Bendl D, Wong B, Rachlin K, et al. (2007) Evaluating biofield treatments in a cell culture model of oxidative stress. Explore (NY) 3: 386-390.

[14] Peck SD (1998) The efficacy of therapeutic touch for improving functional ability in elders with degenerative arthritis. Nurs Sci Q 11: 123-132.

[15] Turner JG, Clark AJ, Gauthier DK, Williams M (1998) The effect of therapeutic touch on pain and anxiety in burn patients. J Adv Nurs 28: 10-20.

[16] Trivedi MK, Patil S, Shettigar H, Gangwar M, Jana S (2015) Antimicrobial sensitivity pattern of Pseudomonas fluorescens after biofield treatment. J Infect Dis Ther 3: 222.

[17] Nayak G, Altekar N (2015) Effect of biofield treatment on plant growth and adaptation. J Environ Health Sci 1: 1-9.

[18] Sances F, Flora E, Patil S, Spence A, Shinde V (2013) Impact of biofield treatment on ginseng and organic blueberry yield. Agrivita J Agric Sci 35: 22-29.

[19] Trivedi MK, Branton A, Trivedi D, Shettigar H, Bairwa K, et al. (2015) Fourier transform infrared and ultraviolet-visible spectroscopic characterization of biofield treated salicylic acid and sparfloxacin. Nat Prod Chem Res 3: 186.

[20] Inoue M, Hirasawa I (2013) The relationship between crystal morphology and XRD peak intensity on $\mathrm{CaSO}_{4} \cdot 2 \mathrm{H}_{2} \mathrm{O}$. J Cryst Growth 380: 169-175.

[21] Hathwar VR, Thakur TS, Row TNG, Desiraju GR (2011) Transferability of multipole charge density parameters for supramolecular synthons: A new tool for quantitative crystal engineering. Cryst Growth Des 11: 616-623.

[22] Trivedi MK, Tallapragada RR (2008) A transcendental to changing metal powder characteristics. Met Powder Rep 63: $22-28,31$.
[23] Behnajady MA, Alamdari ME, Modirshahla N (2013) Investigation of the effect of heat treatment process on characteristics and photocatalytic activity of $\mathrm{TiO}_{2}-\mathrm{UV} 100$ nanoparticles. Environ Prot Eng 39: 33-46.

[24] Katritzky AR, Jain R, Lomaka A, Petrukhin R, Maran U, et al. (2001) Perspective on the relationship between melting points and chemical structure. Cryst Growth Des 1: 261-265.

[25] Zemansky MW (1968) Heat and thermodynamics. (5thedn), McGraw Hill, New York.

[26] Pierre P (1998) A to $Z$ of thermodynamics. Oxford University Press.

[27] Trivedi MK, Branton A, Trivedi D, Nayak G, Singh R (2015) Physical, thermal and spectroscopic characterization of $m$-toluic Acid: An impact of biofield treatment. Biochem Pharmacol (Los Angel) 4: 178.

[28] Espenson JH (1995) Chemical kinetics and reaction mechanisms. (2ndedn) Mcgraw-Hill, U.S.

[29] Morrell CE, Beach LK (1948) Oxidation of aromatic compounds. U.S. Patent 2443832.

[30] Hull EH (1979) Production of N,N-di(ethyl)-meta-toluamide from meta-toluic acid by liquid phase catalytic reaction with diethylamine. U.S. Patent 4133833A.

[31] Johnson AW (1999) Invitation to organic chemistry. Jones \& Bartlett Learning.

[32] http://webbook.nist.gov/cgi/cbook.cgi?ID=C99945\&Type=IRSPEC\&Index $=1 \#$ Refs

[33] Lambert JB (1987) Introduction to organic spectroscopy. Macmillan, New York, USA.

[34] Pavia DL, Lampman GM, Kriz GS (2001). Introduction to spectroscopy. (3rdedn), Thomson Learning, Singapore.

[35] Lang L (1969) Absorption spectra in the ultraviolet and visible region. Akademiai Kiado Publishers, Budapest. 